\title{
Pengembangan Permainan Sirkuit Animove Untuk Menstimulasi Kemampuan Motorik Kasar Anak Usia 5-6 Tahun
}

\author{
Rahmah Dwi Sistiarini \\ Universitas Negeri Malang \\ Email: rahmahihp@gmail.com \\ Orcid ld:0000-0001-6756-8782

\section{Pramono} \\ Universitas Negeri Malang \\ Email: pramono.fip@um.ac.id \\ Tri Munaisra Tirtaningsih \\ Universitas Negeri Malang \\ Email: munaisra.tri.fip@um.ac.id
}

Article received: 07 Juli 2020, Review process: 05 Februari 2021,

Article Accepted: 11 Maret 2021, Article published: 30 Maret 2021

\begin{abstract}
The product developed comprised the Animove (Animal Movement) circuit game. This research and development aims to produce a physical motor learning that can teach gross motor skills, strength, speed, and agility in children aged 5-6 years by focusing on the benefits, safety, and attractiveness in the game. This study utilized the Research and Development (R\&D) method by Borg and Gall which has been approved into the following seven steps: 1) initial research and data collection in the field, 2) planning, 3) developing initial products, 4) initial revisions, 5) conducting trials in small limited groups, 6) revising product improvements, and 7) disseminating or developing through scientific forums at national education seminars. The data were obtained from other early childhood game experts and motor experts. This research employed both qualitative and quantitative methods as data analysis techniques. The instruments used consisted of questionnaires and observation sheets. The results of the expert validation are as follows: (1) game experts stated that $97.22 \%$ of the Animove circuit game was very valid, appropriate and easy for children to play, (2) game instrument experts declared that $84.09 \%$ of the game was very valid, safe, and attractive for children, (3) motor physicists mentioned that $96.43 \%$ of the game was very valid and able to stimulate the gross motor physical development of children aged 5-6 years in Kindergarten group $B$, specifically to improve and correct the agility of children. The small group test revealed that (1) the safety level of the Animove game for children aged 5-6 years reached $91.67 \%$, (2) the ease level of this game reached $95 \%$, and (3) in terms of appearance level, this game reached $96.67 \%$, meaning that it was interesting. Therefore, it can be concluded that the Animove game was very valid and suitable for use in the physical-motor development of early childhood.
\end{abstract}


Keywords: Game Animove, Stimulation, Motor physical, Early childhood

\begin{abstract}
Abstrak
Produk yang dikembangkan adalah berupa permainan sirkuit Animove (Animal Movement). Penelitian dan pengembangan ini bertujuan untuk menghasilkan suatu alternatif pembelajaran fisik motorik yang mampu melatih keterampilan motorik kasar anak khususnya pada kekuatan (Strength), Kecepatan (Speed), Kelincahan (Agility) pada anak usia 5-6 tahun yang memperhatikan aspek kemudahan, keamanan dan kemenarikan pada permainan. Penelitian ini menggunakan metode Research and Development (R\&D) oleh Borg dan Gall yang telah dimodifikasi menjadi tujuh langkah yaitu melakukan: 1) penelitian dan pengumpulan data awal di lapangan, 2) merencanakan, 3) mengembangkan produk awal, 4) revisi awal, 5) melakukan uji coba dalam kelompok kecil terbatas, 6) melakukan revisi penyempurnaan produk dan 7) melakukan diseminasi atau penyebaran pada forum ilmiah pada seminar nasional pendidikan. Data diperoleh dari para ahli antara lain ahli permainan AUD, ahli alat permainan AUD, ahli fisik motorik. Instrument yang digunakan berupa kuesioner/angket dan lembar observasi. Teknik analisis data yang digunakan adalah analisis kualitatif dan kuantitatif. Hasil dari validasi para ahli adalah sebagai berikut: (1) $97,2 \%$ dinyatakan oleh ahli permainan bahwa permainan sirkuit Animove sangat valid, sesuai dan mudah untuk dimainkan anak, (2) ahli alat permainan menyatakan 84,09\% permainan sirkuit Animove sangat valid, aman, dan menarik untuk anak, (3) ahli fisik motorik menyatakan 96,43\% permainan sirkuit Animove sangat valid dan dapat menstimulasi perkembangan fisik motorik kasar anak usia 5-6 tahun di TK B khususnya untuk melatih kekuatan, koordinasi, ketepatan dan kelincahan anak. Pada Uji kelompok kecil, diperoleh data: (1) 91,67\% permainan ini aman untuk anak usia 5-6 tahun, (2) 95\% permainan Animove ini mudah untuk anak usia 5-6 tahun dan (3) 96,67\% permainan ini menarik untuk anak usia 5-6 tahun. Oleh karena itu dapat disimpulkan bahwa permainan Animove sangat valid dan layak untuk dimanfaatkan dalam menstimulasi perkembangan fisik-motorik anak usia dini.
\end{abstract}

Kata Kunci: Permainan Animove, Stimulasi, Fisik motorik, Anak usia dini

\title{
PENDAHULUAN
}

Masa Golden Age adalah masa keemasan yang dialami oleh anak sekali dalam siklus kehidupannya, sehingga masa ini menjadi situasi krisis yang sayang jika terlewati begitu saja. Masa Golden Age anak terjadi pada umur 0-5 tahun, pada fase ini anak akan bertumbuh dan berkembang dengan pesat. Menurut (Prasetiawan, 2019) pada masa ini 70-80\% kinerja otak anak akan bekerja secara optimal. Pada masa inilah peran orang tua dan lingkungan sekitar sangat berperan besar dalam membentuk karakter anak. Ditambah lagi dengan proses pertumbuhan dan perkembangan anak yang sangat pesat, sehingga sangat penting untuk memberikan stimulasi yang tepat dalam mengoptimalkan tumbuh kembang anak. 
Sebagai orang tua pasti sangat memperhatikan tumbuh kembang sang buah hati. Salah satu perkembangan yang harus diperhatikan bagi orang tua adalah perkembangan motorik anak. Menurut (Fadlan \& Pratama, 2019), perkembangan motorik adalah suatu proses pertumbuhan dan perkembangan kemampuan gerak seorang anak, pada dasarnya hal ini akan terjadi sejalan dengan kematangan syaraf dan otot anak. Secara umum perkembangan motorik terbagi menjadi dua, yaitu motorik kasar dan motorik halus. Motorik kasar adalah gerakan tubuh yang melibatkan penggunaan otot-otot besar atau sebagian besar anggota tubuh yang dipengaruhi oleh kematangan anak itu sendiri. Seperti duduk, menendang, berlari, dan naik turun tangga. Sedangkan untuk motorik halus adalah gerakan yang melibatkan penggunaan otot-otot halus atau sebagian anggota tubuh tertentu yang dipengaruhi oleh kesempatan untuk belajar dan berlatih. Seperti menulis, menggunting, dan menyusun puzzle.

Perkembangan fisik motorik anak dipengaruhi oleh 2 faktor, yaitu faktor internal dan eksternal. Faktor internal ini adalah kematangan kerja pada struktur tubuh, seperti pada otot dan tulang anak. Sedangkan faktor eksternal terdapat pada lingkungan yang memberi stimulasi yang tepat agar anak dapat berkembang secara optimal. Menurut (Pramono, 2015), pemberian stimulasi yang sesuai dengan dunia anak-anak adalah dengan kegiatan bermain yang menyenangkan. Sehingga sudah seharusnya membiarkan anak-anak untuk bermain dengan riang gembira. Banyak manfaat yang di dapat ketika anak bermain, guna menunjang masa berkembangnya. American Academy of Pediatrics (AAP) dalam (Ramsetter \& Murray, 2017) berpendapat bahwa dengan bermain otak anak akan terstimulasi, meningkatkan ikatan sosial dan emosional antara anak dan orang tua maupun teman sebayanya. Selain itu juga dengan bermain anak dapat mengoptimalkan pertumbuhannya, lewat aktivitas fisik yang dilakukan anak ketika bermain.

Secara tidak langsung fisik motorik pada kebugaran jasmani anak dapat dilatih melalui permainan. Namun hal yang perlu diperhatikan selain permainan tersebut dapat memberikan rasa senang, permainan juga harus dikemas sesuai dengan tahapan perkembangan usia anak, sehingga dapat memberikan rangsangan stimulasi yang tepat bagi anak. Menurut (Harlock, 1987) dengan bermain anak akan memperoleh pengalaman yang akan membentuk pengetahuan dan kemampuannya. Hal inilah yang menjadi penyebab utama, mengapa setiap pembelajaran yang disajikan oleh guru kepada AUD harus memiliki unsur bermain di dalamnya. 

berikut.

Adapun beberapa definisi dan teori permainan menurut para ahli sebagai

Tabel 1 Teori dan Definisi Permainan Menurut Beberapa Ahli

\begin{tabular}{|c|c|c|}
\hline Teori & Ahli & Definisi \\
\hline Teori Rekreasi & $\begin{array}{l}\text { Schaller \& Narzarus } \\
\text { di Jerman pada tahun } \\
\text { 1841-1884 }\end{array}$ & $\begin{array}{l}\text { Permainan adalah suatu kesibukan yang } \\
\text { rekreatif, yang berlawanan dengan kerja serta } \\
\text { keseriusan hidup. Pada teori ini biasanya } \\
\text { orang dewasa mencari kegiatan refreshing } \\
\text { untuk menghilangkan rasa lelah setelah } \\
\text { bekerja atau melakukan kegiatan-kegiatan } \\
\text { tertentu. }\end{array}$ \\
\hline
\end{tabular}

\begin{tabular}{llr}
\hline Teori & Hebert & Spancer \\
Pemunggahan & seorang & sarjana \\
(Ontlading & kebangsaan & Inggris \\
Stheorie) & $1820-1903$ &
\end{tabular}

Terjadinya suatu permainan disebabkan oleh mengalir keluarnya energi, yaitu tenaga yang telah menumpuk pada diri anak sehingga energi tersebut menuntut untuk dimanfaatkan atau dipekerjakan. Sehubungan dengan energi yang "mencair" dan "mengunggah" kedalam suatu permainan. Oleh karena itu teori ini sering juga disebut dengan teori "kelebihan tenaga" (krachtoverschot-theorie). Sehingga pada teori ini permainan merupakan katup pengaman bagi energi vital yang berlebihan.

\begin{tabular}{lll}
\hline Teori Biologis & Dikemukakan Permainan merupakan tugas biologis yang \\
& pertama kali oleh Karl dapat melatih macam-macam fungsi, baik itu \\
& Groos seorang fungsi rohan hingga kefungsi rohani. \\
& sarjana kebangsaan Sehingga waktu bermain merupakan \\
& Jerman, yang kesempatan baik bagi anak untuk beradaptasi \\
& dikemudian hari terhadap lingkunagan hidupnya. \\
& Maria Montessori \\
& juga sepemahaman \\
dengan teori ini
\end{tabular}

\section{Sumber: (Farhurohman, 2017)}

Berdasarkan beberapa definisi dan teori permainan beberapa tokoh diatas, dapat di simpulkan bahwa Permainan adalah suatu bentuk aktivitas yang menyenangkan sebagai pencerminan realitas dalam memperoleh pengetahuan. Oleh karena itu permainan sangat baik bagi anak. Disamping anak memperoleh rasa senang, anak juga dapat mengasah pengalaman dan pengetahuannya ketika bemain.

Permainan Animove adalah permainan sirkuit yang dirancang untuk menstimulasi fisik motorik kasar anak usia 5-6 tahun. Nama Animove merupakan singkatan dari Animal Movement yang berasal dari kata bahasa inggris, memiliki arti gerakan binatang. Pada permainan ini terdiri dari 4 pos, yang masing-masing posnya memiliki berbagai gerakan binatang seperti melompat kangguru, merangkak seperti simpanse, melempar buah kekeranjang monyet dan berjalan zig-zag seperti ular. Aktivitas yang dilakukan ini bertujuan untuk menstimulasi motorik kasar pada kekuatan (melompat dengan kedua kaki), koordinasi 
(merangkak mengikuti pola jejak), ketepatan (melempar buah plastik kedalam keranjang), dan kelincahan (berjalan zig-zag).

Penting agar memberikan berbagai rangkaian stimulus pada aktivitas, yang dapat mengoptimalkan motorik anak pada kebugaran jasmani yang meliputi kekuatan (strength), daya tahan (endurance), kecepatan (speed), kelincahan (agility), kelenturan (flexibility), koordinasi (coordination), ketepatan (accuracy), keseimbangan (balanced) (Rismayanthi, 2018). Kebugaran jasmani ini dapat dilatih dengan gerakan seperti berjalan, berlari, melompat, meloncat dan berbagai kegiatan lainnya yang melibatkan penggunaan otot besar.Secara tidak langsung fisik motorik dalam kebugaran jasmani dapat dilatih dengan cara permainan yang memberikan rasa senang kepada anak. Namun permainan tersebut juga harus dikemas sesuai dengan fisik motorik anak, serta capaian perkembangan usianya.

\section{Tabel 2 Standar Tingkat Pencapaian Perkembangan Anak (STPPA)}

\begin{tabular}{|c|c|}
\hline $\begin{array}{l}\text { Lingkup } \\
\text { Perkembangan }\end{array}$ & Tingkat Pencapaian Perkembangan Anak Usia 5-6 tahun \\
\hline $\begin{array}{l}\text { II Fisik Motorik } \\
\text { 1. Motorik kasar }\end{array}$ & $\begin{array}{l}\text { 1. Melakukan gerakan tubuh secara terkoordinasi untuk } \\
\text { melatih kelenturan, keseimbangan, dan kelincahan } \\
\text { 2. Melakukan koordinasi gerakan mata-kaki-tangan- } \\
\text { kepala dalam menirukan tarian atau senam } \\
\text { 3. Melakukan permainan fisik dengan aturan } \\
\text { 4. Terampil menggunakan tangan kanan dan kiri } \\
\text { 5. Melakukan kegiatan kebersihan diri }\end{array}$ \\
\hline 2. Motorik Halus & $\begin{array}{l}\text { 1. Menggambar sesuai gagasannya } \\
\text { 2. Meniru bentuk } \\
\text { 3. Melakukan eksplorasi dengan berbagai media dan } \\
\text { kegiatan } \\
\text { 4. Menggunakan alat tulis dan alat makan dengan benar } \\
\text { 5. Menggunting sesuai dengan pola } \\
\text { 6. Menempel gambar dengan tepat } \\
\text { 7. Mengekspresikan diri melalui gerakan menggambar } \\
\text { secara rinci }\end{array}$ \\
\hline
\end{tabular}

\section{Sumber: Permendikbud No. 146 Tahun 2014 Lampiran 1 (STPPA)}

Standart Tingkat Pencapaian Perkembangan Anak (STPPA) ini merupakan standart yang menjadi bahan acuan guru di Indonesia dalam melakukan teknik penilaian anak. Pada STPPA program PAUD memiliki muatan indikator-indikator kompetensi yang dapat mengembangkan aspek fisik motorik anak sesuai dengan tahapan usianya. Pada khususnya dalam perkembangan dari unsur kematangan dalam pengendalian tubuh. Terdapat hubungan yang saling terkait antara kebugaran tubuh dalam jasmani, keterampilan motorik, dan kontrol motorik. Dalam hal ini kontrol motorik tidak akan berkembang secara optimal tanpa kebugaran tubuh. Sedangkan kebugaran tubuh tidak akan tercapai tanpa adanya latihan fisik yang rutin.

Guna memperkuat penelitian yang dilakukan, peneliti melakukan beberapa kajian pustaka untuk mencari tahu apakah ada penelitian pengembangan sirkuit untuk AUD sebelumnya. Akhirnya peneliti menemukan 3 (tiga) penelitian terdahulu, penelitian yang pertama diteliti oleh (Pratiwi, 2019) dengan judul "Pengembangan Permainan Mini Junggle Sircuit Untuk Melatih Kemampuan 
Berpikir Simbolik Anak Kelompok A Kota Malang". Hasil penelitian tersebut menunjukan bahwa model pembelajaran permainan modifikasi memberikan pengaruh pada kemampuan kognitif dan motorik kasar anak. Oleh karena itu pembelajaran permainan modifikasi ini dapat digunakan sebagai alternatif pelajaran pada aspek kognitif untuk AUD. Selain itu salah satu keberhasilan dalam suatu media adalah memiliki kualitas teknis berdasarkan tujuan pembelajaran yaitu membangkitkan minat atau partisipasi anak dalam mengikuti kegiatan pembelajaran yang sejalan dengan konsep yang telah dirancang dalam permainan Mini Junggle Sirkuit. Penelitian serupa juga pernah dilakukan oleh (Kurniawati, 2015) dengan judul "Pengembangan Media Fun Circle Sircuit Untuk Pembelajaran Aspek Fisik Motorik di TK Kelompok B". Hasil dari penelitian ini adalah Produk pengembangan permainan dapat menjadikan pembelajaran fisik motorik lebih bermakna karena dirancang semenarik mungkin dan inovatif, sehingga tidak hanya dapat di gunakan oleh guru, tetapi juga dapat dimanfaatkan oleh anak. Selain itu, media permainan dirancang untuk menstimulus fisik motorik anak, juga dalam kemampuan bahasa dan kemampuan agama dan moral anak. Selain penelitian yang dilakukan oleh Pratiwi dan Kurniawati, Peneliti juga menemukan penelitian yang serupa yang dilakukan oleh (Noviana, 2015) dengan judul "Permainan Sirkuit Hula-hoop dalam Pembelajaran Fisik Motorik Anak Kelompok B di TK Gugus II Kecamatan Srengat Kabupaten Blitar". Kesimpulan dari hasil penelitian ini adalah kurang adanya variasi dalam pembelajaran fisik motorik yang di berikan guru menyebabkan anak merasa bosan saat pembelajaran, sehingga dengan menerapkan permainan yang telah dimodifikasi ini dapat menjadi alternatif yang menarik dan menyenangkan di TK. Permainan sirkuit adalah suatu program latihan yang dikombinasikan dari beberapa item-item latihan yang bertujuan untuk membuat latihan menjadi tidak membosankan dan lebih efesien.

Berdasarkan dari hasil penyebaran angket analisis kebutuhan pembelajaran motorik kasar di lembaga yang dilakukan oleh peneliti di 5 lembaga TK (RA Muslimat NU 11, TK Syuhada, TK Akademika TK Dharma Bhakti Pertiwi, dan TK ABA 7) dari lima lembaga tersebut $100 \%$ guru menyatakan bahwa metode yang paling sering digunakan untuk menstimulasi keterampilan motorik kasar anak adalah melalui permainan. Terdapat $60 \%$ guru di lembaga PAUD yang belum pernah menggunakan permainan sirkuit kepada anak dalam menstimulasi keterampilan fisik motorik anak. Padahal $100 \%$ guru di lembaga PAUD menyatakan permainan yang paling efektif adalah melalui permainan sirkuit. Dengan $100 \%$ guru menyatakan bahwa perlu untuk membuat suatu permainan sirkuit yang mudah, menyenangkan, dan aman untuk melatih fisik motorik anak di sekolah. Sehingga dengan permainan sirkuit ini anak lebih tertarik dalam mengikuti pembelajaran.

Berdasarkan uraian diatas dan kebutuhan akan permainan sirkuit, akhirnya peneliti mencari suatu alternatif untuk merancang serta mengembangkan suatu permainan sirkuit yang mampu menstimualsi fisik motorik anak yang memperhatikan aspek kemudahan, keamanan dan kemenarikan bagi anak. Selain memperhatikan nilai kepraktisan dan keamanan dalam permainan ini, permainan Animove juga akan memberikan perasaan senang pada anak. Maka peneliti 
membuat suatu penelitian dengan judul "Pengembangan Permainan Sirkuit 'Animove' Untuk Menstimulasi Keterampilan Motorik Kasar Anak Usia 5-6 Tahun”.

\section{METODOLOGI}

Peneliti telah melakukan modifikasi terhadap kesepuluh langkah metode penelitian $R \& D$ milik Borg \& Gall (Sukmadinata, 2005) tersebut menjadi tujuh langkah pelaksanaan penelitian dan pengembangan, yang telah tersaji kedalam gambar skema prosedur penelitian dan pengembangan permainan Animove ini sebagai berikut:

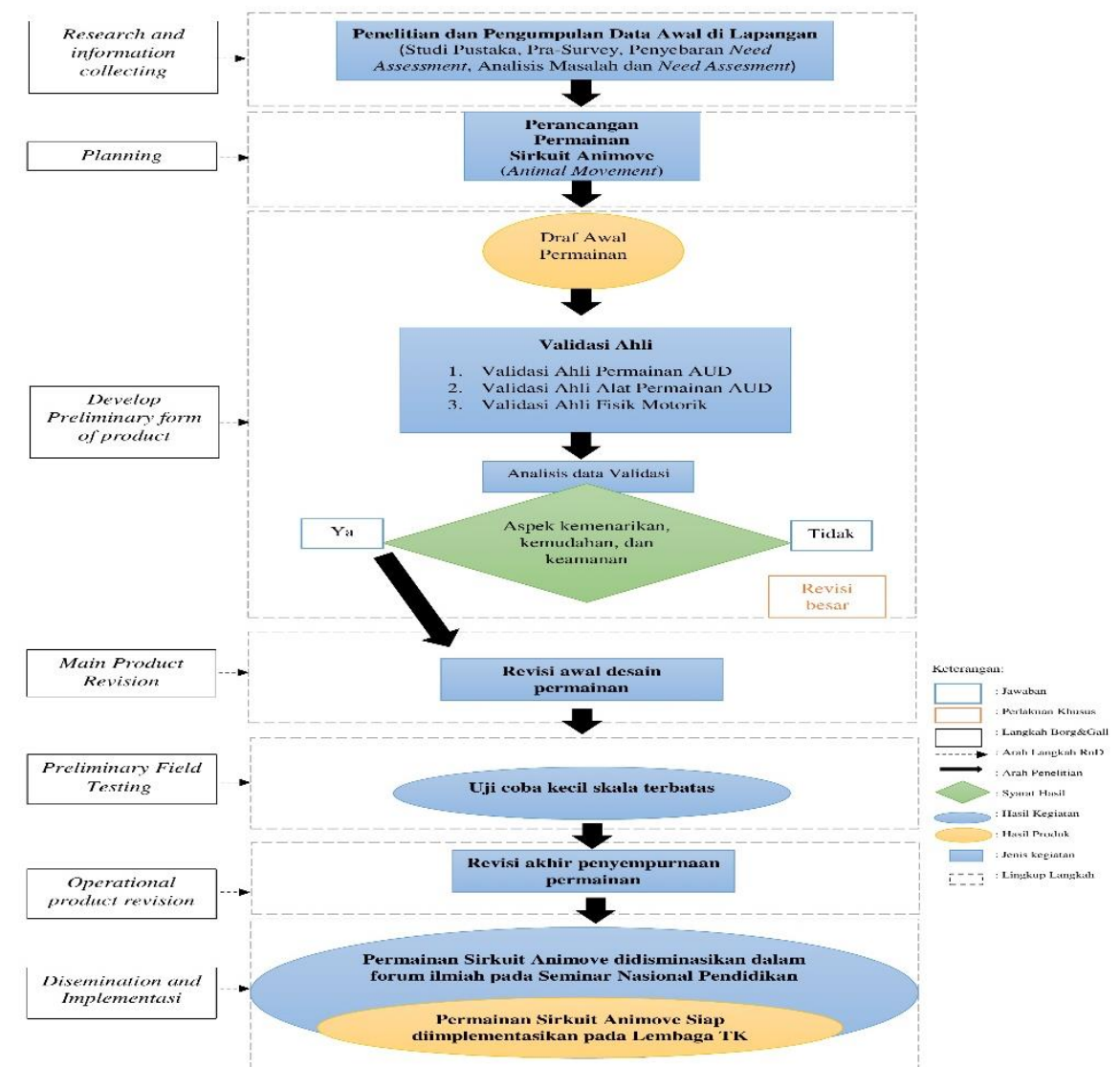

\section{Gambar 1 Skema Prosedur Penelitian dan Pengembangan Model Borg dan Gall Modifikasi Peneliti}

Metode penelitian yang digunakan oleh peneliti adalah Resserch and Development (R\&D) oleh Borg dan Gall. Metode ini memiliki sepuluh langkah yang akan dimodifikasi menjadi tujuh langkah karena situasi dan kondisi yang terjadi dilapangan. Adapun diagram alur penelitian seperti gambar diatas. Prosedur penelitian dan pengembangan dapat dimodifikasi dan bukanlah sesuatu hal yang baku. Hal ini sejalan dengan pendapat Ardana dalam (Murdani, 2015) setiap peneliti pada penelitian pengembangan tentu saja dapat memilih dan menentukan langkah-langkah apa saja yang paling tepat dalam penelitiannya, dengan mempertimbangkan kondisi yang ada dalam proses pengembangan dan situasi yang terjadi di lapangan. Dikarenakan kondisi pandemik virus Covid-19 menyebabkan terjadinya physical distancing yang membuat uji coba dilapangan 
khususnya di satuan lembaga PAUD ini tidak dimungkinkan untuk dilakukan, akhirnya peneliti mengambil keputusan untuk melakukan penelitian hingga validasi ahli dan uji coba kelompok kecil dengan skala terbatas saja tanpa melakukan uji coba sekala besar di lapangan.

Pengembangan permainan ini dilaksanakan dalam beberapa tahap yaitu: (1) Research and information collecting (Penelitian dan pengumpulan data). Pada tahap ini peneliti melakukan penelitian dan pengumpulan data informasi seperti mencari kajian pustaka, melakukan observasi, pengamatan kelas, menyebarkan angket need assessment, dokumentasi, menganalisis kebutuhan yang ada di lapangan serta mempersiapkan laporan pokok dalam permasalahan yang ada, (2) Planning (Perencanaan). Pada tahap ini peneliti melakukan perencanaan dengan melakukan penyusunan rancangan dalam "Pengembangan Permainan Sirkuit Animove untuk Melatih Keterampilan Motorik Kasar Anak Usia 5-6 Tahun" seperti melakukan pendefinisikan keterampilan, perumusan tujuan penelitian, atau menentukan urutan dalam pembelajaran, yang selanjutnya akan divalidasi oleh para ahli, (3) Develop preliminary form of product (Pengembangan draf produk). Pada tahap ini peneliti mengembangkan bentuk produk awal rancangan "Pengembangan Permainan Sirkuit Animove untuk Melatih Keterampilan Motorik Kasar Anak Usia 5-6 Tahun" setelah divalidasi oleh para ahli pembelajaran AUD dan fisik motorik. 4) Main product revision (Revisi produk utama), revisi produk sebagaimana disarankan oleh para validasi ahli, (5) Preliminary field testing (Uji coba kecil skala terbatas), melakukan uji lapangan awal terhadap desain produk, yang bersifat terbatas, baik substansi desain maupun pihak-pihak yang terlibat. (6) Operational product revision (Penyempurnaan produk hasil uji coba lapangan), pada tahap ini peneliti melakukan revisi produk (berdasarkan saran-saran dari hasil uji validasi ahli dan uji coba kelompok kecil terbatas). (7) Desiminasion and implementation (Diseminasi dan implementasi) pada tahap ini peneliti melakukan pelaporan produk pada forum profesional seperti seminar nasional pendidikan guna mendapatkan masukan dan saran dalam rangka menambah keabsahan produk untuk diimplementasikan pada anak usia 5-6 tahun di lembaga TK.

Instrumen yang digunakan pada penelitian pengembangan permainan Animove ini adalah menggunakan kuisioner need assessment yang instrumen validasi ahli yang digunakan untuk pemerolehan data kuantitatif dan kualitatif. Terdapat dua jenis data yang diperoleh oleh peneliti, yaitu data kualitatif dan data kuantitatif. Data kualitatif diperoleh dari hasil tinjuan para ahli yang berupa saran dan masukan, serta hasil wawancara pada penelitian awal di 5 TK yang tersebar di kota Malang antara lain RA Muslimat NU 11, TK Syuhada, TK Akademika, TK Dharma Bhakti Pertiwi, TK ABA 7. Sedangkan data kuantitatif diperoleh dari jawaban skor para ahli yang menjadi validator permainan sirkuit Animove ini.

Subjek penelitian dan pengembangan ini adalah: Subjek penelitian data awal analisis kebutuhan (Need Assesment) yang terlibat antara lain; 5 orang guru dari 5 lembaga TK di kota Malang. Subyek evaluasi ahli terdiri dari: 1 orang ahli pemainan AUD, 1 orang ahli alat permainan AUD dan 1 orang ahli fisik motorik. Subjek uji coba kecil skala terbatas terdiri dari 5 orang anak usis 5-6 tahun.

Teknik analisis data menggunakan teknik analisis deskriptif kualitatif dan kuantitatif. 1) data kualitatif diperoleh berdasarkan saran, masukan dan evaluasi para ahli, 2) sedangkan data kuantitatif didapat dari hasil uji coba kelompok kecil skala terbatas dan pernyataan para ahli yang berupa nilai skor yang bertujuan 
untuk menyempurnaan produk. Teknik analisis ini diperoleh dari kuesioner yang telah dibagikan kepada subjek penelitian, untuk mempermudah pemerolehan kesimpulan, hasil analisis persentase akan digolongkan sesuai dengan data persentase yang diperoleh. Teknik pemaknaan dan pengkatagorian yang digunakan sebagai berikut:

Tabel 3. Tabel Kriteria Persentase

\begin{tabular}{ccc}
\hline Kategori & Persentase & Kualifikasi \\
\hline 4 & $80 \%-100 \%$ & Sangat Baik \\
\hline 3 & $60 \%-79 \%$ & Baik \\
\hline 2 & $50 \%-59 \%$ & Kurang Baik \\
\hline 1 & $0 \%-49 \%$ & Tidak Baik \\
\hline
\end{tabular}

\section{Sumber (Akbar 2013:82)}

\section{HASIL DAN PEMBAHASAN}

Berdasarkan dari pengumpulan data yang diperoleh dari penyebaran angket analisis kebutuhan kepada 5 orang guru di 5 TK yang tersebar di kota Malang (RA Muslimat NU 11, TK Syuhada, TK Akademika, TK Dharma Bhakti Pertiwi, TK ABA 7), hasil dari evaluasi produk yang dilakukan oleh 3 orang ahli yaitu: 1 ahli permainan AUD, 1 ahli alat permainan AUD, dan 1 ahli fisik motorikdan hasil dari uji coba kecil skala terbatas.

Berdasarkan dari hasil penyebaran angket analisis kebutuhan pembelajaran motorik kasar di lembaga yang dilakukan oleh peneliti di 5 lembaga di kota Malang, ditemukan 100\% guru menyatakan bahwa metode yang paling sering digunakan untuk menstimulasi keterampilan motorik kasar anak adalah melalui permainan. Terdapat $60 \%$ guru di lembaga PAUD yang belum pernah menggunakan permainan sirkuit kepada anak dalam menstimulasi keterampilan fisik motorik anak. Padahal $100 \%$ guru di lembaga PAUD menyatakan permainan yang paling efektif adalah melalui permainan sirkuit. Dengan $100 \%$ guru menyatakan bahwa perlu untuk membuat suatu permainan sirkuit yang mudah, menyenangkan, dan aman untuk melatih fisik motorik anak di sekolah. Sehingga dengan permainan sirkuit ini anak akan lebih tertarik dalam mengikuti pembelajaran.

Adapun guru yang memilih 3 aspek yang paling dibutuhkan saat ini untuk dilatih dan diimplikasikan menjadi suatu permainan adalah sebagai berikut: 


\section{Aspek motorik yang distimulasi}

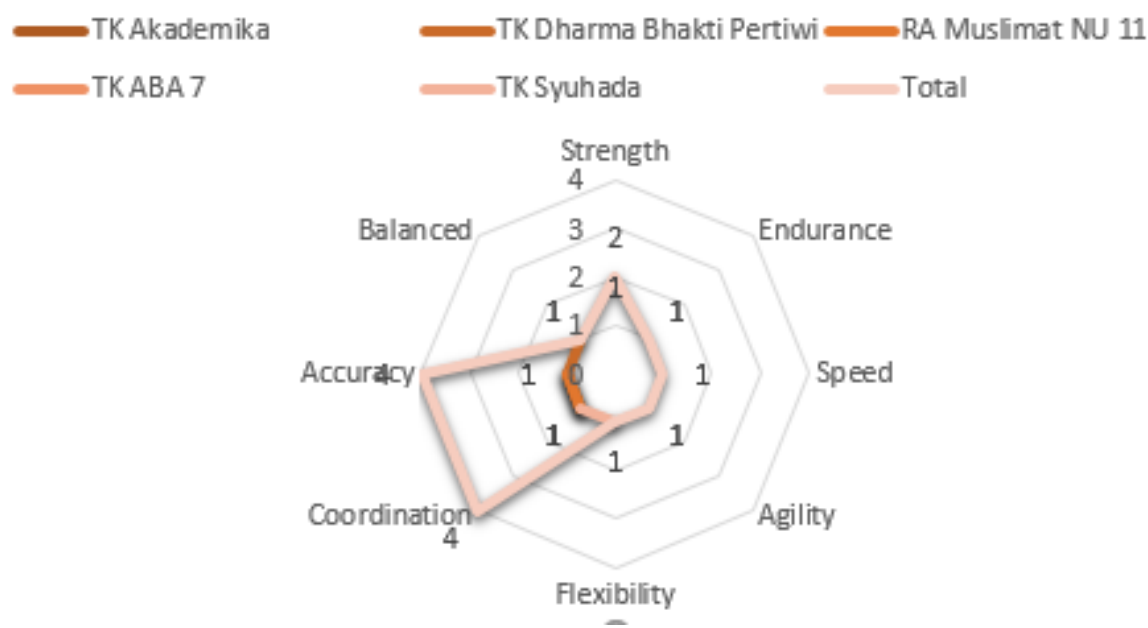

\section{Gambar 2. Aspek Fisik Motorik Yang Distimulasi}

Berdasarkan Gambar 2 pada diagram radar di atas terdapat 2 guru yang memilih untuk menstimulasi unsur motorik kasar anak pada unsur kekuatan, terdapat 1 guru yang memilih untuk menstimulasi unsur motorik kasar anak pada unsur daya tahan, terdapat 1 guru yang memilih untuk menstimulasi unsur motorik kasar anak pada unsur kecepatan, terdapat 1 guru yang memilih untuk menstimulasi unsur motorik kasar anak pada unsur kelincahan, terdapat 1 guru yang memilih untuk menstimulasi unsur motorik kasar anak pada unsur kelenturan. Terdapat 4 guru yang memilih untuk menstimulasi unsur motorik kasar anak pada unsur koordinasi, terdapat 4 guru yang memilih untuk menstimulasi unsur motorik kasar anak pada unsur ketepatan dan ada 1 orang guru yang memilih untuk menstimulasi unsur motorik kasar anak pada unsur keseimbangan. Sehingga dapat disimpulkan bahwa, dari kedelapan unsur-unsur motorik kasar anak usia 5-6 tahun terdapat 3 (tiga) unsur motorik kasar yang sangat penting untuk diberikan stimulasi. Ketiga unsur tersebut adalah unsur motorik kasar koordinasi (coordination), ketepatan (accuracy), dan kekuatan (strength).

Berdasarkan uraian di atas dapat disimpulkan bahwa dari kedelapan unsur-unsur motorik kasar anak usia 5-6 tahun yang sangat urgent untuk diberikan stimulasi adalah unsur motorik kasar koordinasi (coordination), ketepatan (accuracy), dan kekuatan (strength). Sehingga peneliti mengembangan pemainan sirkuit Animove untuk menstimulasi ketiga unsur motorik kasar anak pada usia 5-6 tahun yang dilengkapi dengan buku panduan. Sehingga guru dapat mengimplementasikan permainan secara otodidak di sekolahnya masing-masing.

Buku panduan yang dibuat untuk guru sebagai panduan permainan Animove berisikan materi tentang: 1) pengertian permainan Animove 2) tujuan permainan Animove 3) manfaat permainan Animove 4) peralatan yang dibutuhkan untuk bermain Animove 5) langkah langkah permainan Animove, 6) aturan permainan Animove, 7) setting Permainan Animove, 8) skenario permainan Animove. 


\section{A. Validasi Para Ahli}

Validasi ahli permainan Animove dilakukan oleh tiga orang ahli di bidangnya masing-masing antara lain: ahli permainan, ahli alat permainan AUD dan ahli fisik motorik. Berdasarkan evaluasi ahli permainan AUD dilakukan oleh Dosen Fakultas IImu Pendidikan Program Studi PG-PAUD Universitas Negeri Malang yaitu Wuri Astuti S.Pd, M.Pd dan memperoleh skor 35 dari skor maksimal 36, jika skor ini dipersentasekan akan memperoleh nilai 97,2\%. Hasil ini diperoleh dari angket instrumen validator ahli permainan AUD dengan jumlah 8 pertanyaan secara keseluruhan. Selaras dengan itu, dapat diketahui bahwa produk permainan Animove yang dikembangkan ini berada pada kriteria persentase $80-100 \%$. Persentase ini menunjukan bahwa permainan ini termasuk kedalam kualifikasi sangat layak dengan kategori dapat digunakan tanpa revisi (Akbar, 2013). Analisis dari data kualitatif diperoleh berdasarkan saran dan masukan oleh ahli permainan AUD, yaitu: mempertimbangkan tempat saat dilaksanakan uji coba dan jumlah alat dan bahan permainan yang disediakan, sehingga tercapainya keefisienan waktu. Mempertimbangkan kembali pemilihan warna pada gambar jejak simpanse, dengan menyelaraskan warna tangan kanan, tangan kiri, kaki kanan, dan kaki kiri dengan satu warna yang berbeda beda. Sedangkan untuk pola ular yang terdapat pada pos 4 terbilang cukup rapat lebih baik agar aktivitas berlari zig-zag diganti dengan berjalan zig-zag. Saat uji coba dilakukan pastikan anak-anak melakukan aktivitas-aktivitas tersebut dengan sikap tubuh yang benar. Saran dan masukan yang diberikan oleh ahli permainan ini dimaksudkan agar anak tidak kesusahan saat melakukan permainan dan anak mengikuti aturan dan lintasan yang telah dibuat.

Berdasarkan evaluasi ahli permainan AUD dilakukan oleh Dosen Fakultas ilmu Pendidikan Program Studi PG-PAUD Universitas Negeri Malang yaitu Drs. Usep Kustiawan, M.Sn memperoleh skor 37 dari skor maksimal 44, jika skor ini dipersentasekan akan memperoleh nilai 84,09 \%. Hasil ini diperoleh dari angket instrument validator ahli alat permainan AUD dengan jumlah 11 pertanyaan secara keseluruhan. Selaras dengan itu, dapat diketahui bahwa permainan Animove yang dikembangkan ini berada pada kriteria persentase $80-100 \%$. Persentase ini menunjukan bahwa permainan ini termasuk kedalam kualifikasi sangat layak dengan kategori dapat digunakan tanpa revisi (Akbar, 2013). Analisis dari data kualitatif diperoleh berdasarkan saran dan masukan oleh ahli alat permainan AUD, yaitu: mempertimbangkan pemilihan warna yang lebih menarik pada hula-hoop rotan. Memastikan kembali alat dan bahan yang digunakan telah aman untuk digunakan anak usia 5-6 tahun. Saran dan masukan dari ahli alat permainan AUD ini dimaksudkan agar permainan ini menarik dan aman dengan memperhatikan keselamatan anak ketika proses bermain.

Berdasarkan evaluasi ahli fisik motorik dilakukan oleh Dosen Fakultas ilmu Keolahragaan Universitas Negeri Malang yaitu Dr. Ari Wibowo Kurniawan, M.Pd memperoleh skor 27 dari skor maksimal 28, jika skor ini dipersentasekan akan memperoleh nilai 96,43 \%. Hasil ini diperoleh dari angket instrumen validator ahli fisik motorik dengan jumlah 7 pertanyaan secara keseluruhan. Selaras dengan itu, dapat diketahui bahwa produk permainan Animove yang dikembangkan ini berada pada kriteria persentase $80-100 \%$. Persentase ini menunjukan bahwa permainan ini termasuk kedalam kualifikasi sangat layak dengan kategori dapat digunakan tanpa revisi (Akbar, 2013). Analisis dari data kualitatif diperoleh 
berdasarkan saran dan masukan oleh ahli fisik motorik, yaitu: mempertimbangkan jarak dan tingkat kesulitan permainan, yang memenuhi karakteristik fisik motorik anak usia 5-6 tahun. Saran dan masukan dari ahli fisik motorik ini dimaksudkan agar stimulasi yang diberikan dalam permainan ini dapat secara maksimal mengoptimalkan perkembangan fisik motorik kasar anak usia 5-6 tahun.

\section{B. Uji Coba Kelompok Kecil Sekala Terbatas}

Data uji coba kelompok kecil terbatas diperoleh dari hasil observasi terhadap produk awal permainan sirkuit Animove untuk menstimulasi keterampilan fisik motorik kasar anak usia 5-6 tahun. Uji coba ini dilakukan pada 5 orang subjek anak usia 5-6 tahun. Adapun data hasil uji coba kelompok kecil terbatas ini terkait dengan aspek kemenarikan, keamanan, dan kemudahan yang disajikan dalam tabel berikut ini.

Tabel 4. hasil uji coba kelompok kecil terbatas ini terkait dengan aspek kemenarikan, keamanan, dan kemudahan.

\begin{tabular}{clccc}
\hline No & Aspek yang dinilai & SC & SI & Pr (\%) \\
\hline 1 & Kemudahan & 110 & 120 & 91,67 \\
\hline 2 & Keamanan & 114 & 120 & 95,00 \\
\hline 3 & Kemenarikan & 116 & 120 & 96,67 \\
\hline Jumlah skor yang diperoleh & $\mathbf{3 4 0}$ & $\mathbf{3 6 0}$ & $\mathbf{9 4 , 4 5}$
\end{tabular}

Berdasarkan tabel di atas, dapat ditarik kesimpulan bahwa jumlah seluruh skor yang diperoleh pada uji coba kecil skala terbatas sebesar 340 dari skor ideal 360. Jika dipersentasekan maka akan diperoleh hasil sebesar 94,45\%. Oleh karena itu uji coba kelompok kecil terbatas berada pada kualifikasi sangat layak dengan kategori permainan dapat digunakan tanpa revisi.

\section{Revisi Produk}

Revisi pada rancangan permainan sirkuit Animove adalah berdasarkan saran dan masukan dari para ahli dan uji coba kecil skala terbatas menjadi bahan dasar dalam melakukan revisi produk. Revisi yang didasarkan para ahli permainan, alat permainan dan fisik motorik dan masukan setelah melakukan uji coba kecil sekala terbatas adalah sebagai berikut: 1) mempertimbangkan pemilihan warna yang lebih menarik pada hula-hoop rotan. 2) mempertimbangkan kembali pemilihan warna pada gambar jejak simpanse, dengan menyelaraskan warna tangan kanan, tangan kiri, kaki kanan, dan kaki kiri dengan satu warna yang berbeda beda, 3) karena pola ular yang terdapat pada pos 4 liukan ular terbilang cukup rapat lebih baik agar berlari zig-zag diganti dengan berjalan zigzag, dan 4) Sasaran untuk melempar buah diameter pada keranjang terlalu kecil. Secara umum revisi pengembangan permainan Animove dapat dilihat sebagai berikut ini. 
AWLADY: Jurnal Pendidikan Anak

Homepage: www.syekhnurjati.ac.id/jurnal/index.php/awlady

Tabel 4.4 Revisi Produk

\begin{tabular}{|c|c|c|}
\hline No & Sebelum Direvisi & Sesudah Direvisi \\
\hline 1. & Warna hula- hoop rotan belum di cat & Hula-hoop dicat agar warna lebih \\
\hline 2. & $\begin{array}{l}\text { Tampilan banner jejak kaki dan tangan } \\
\text { berwarna-warni tanpa ketentuan }\end{array}$ & $\begin{array}{l}\text { Tampilan banner jejak kaki dan tangan } \\
\text { dengan ketentuan; (kaki kanan- } \\
\text { berwarna merah magenta, kaki kiri- } \\
\text { berwarna biru, tangan kanan- } \\
\text { berwarna oren, tangan kiri- berwarna } \\
\text { hijau) }\end{array}$ \\
\hline 3. & $\begin{array}{l}\text { Tampilan Banner Ular brrwarna hitam } \\
\text { kurang bervariasi }\end{array}$ & $\begin{array}{l}\text { Tampilan warna Banner ular diganti } \\
\text { menjadi warna hijau dengan motif ular } \\
\text { sanca agar menarik }\end{array}$ \\
\hline $\begin{array}{c}\uparrow \\
28 \mathrm{cr}\end{array}$ & & 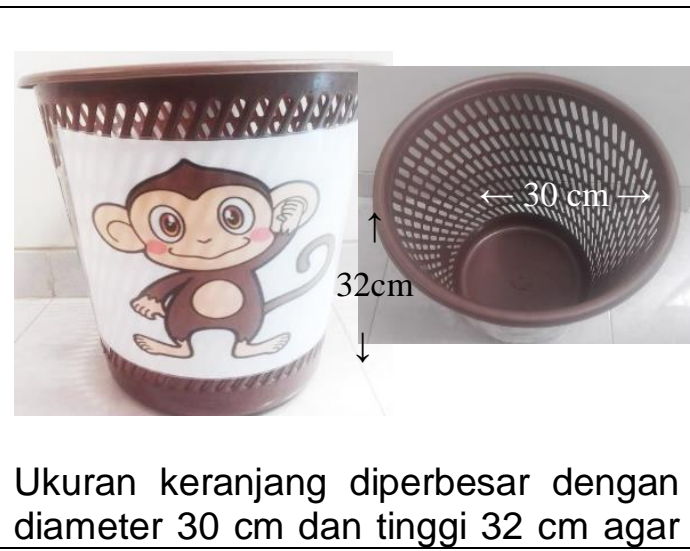 \\
\hline
\end{tabular}


Ukuran keranjang dengan diameter 23 $\mathrm{cm}$ dan tinggi $28 \mathrm{~cm}$ terlalu kecil

Revisi produk ini dilakukan berdasarkan pada saran para ahli validasi dan uji coba kecil skala terbatas dengan kriteria pemilihan permainan yang aman, mudah dan menarik. Permainan yang aman apabila media dan peralatan permainan yang digunakan tidak membahayakan bagi anak. Contohnya seperti peralatan yang tidak ada serat kayu atau bambu yang kasar, tidak ada bulu yang menimbulkan rasa gatal, tidak ada bagian yang tajam atau runcing, cat yang digunakan tidak beracun dan tidak berbau menyengat, paku tidak menonjol. Permainan yang mudah apabila anak tidak mengalami kesulitan ketika bermain, karena permainannya memiliki tingkat kesulitan yang telah disesuaikan dengan umur 5-6 tahun.

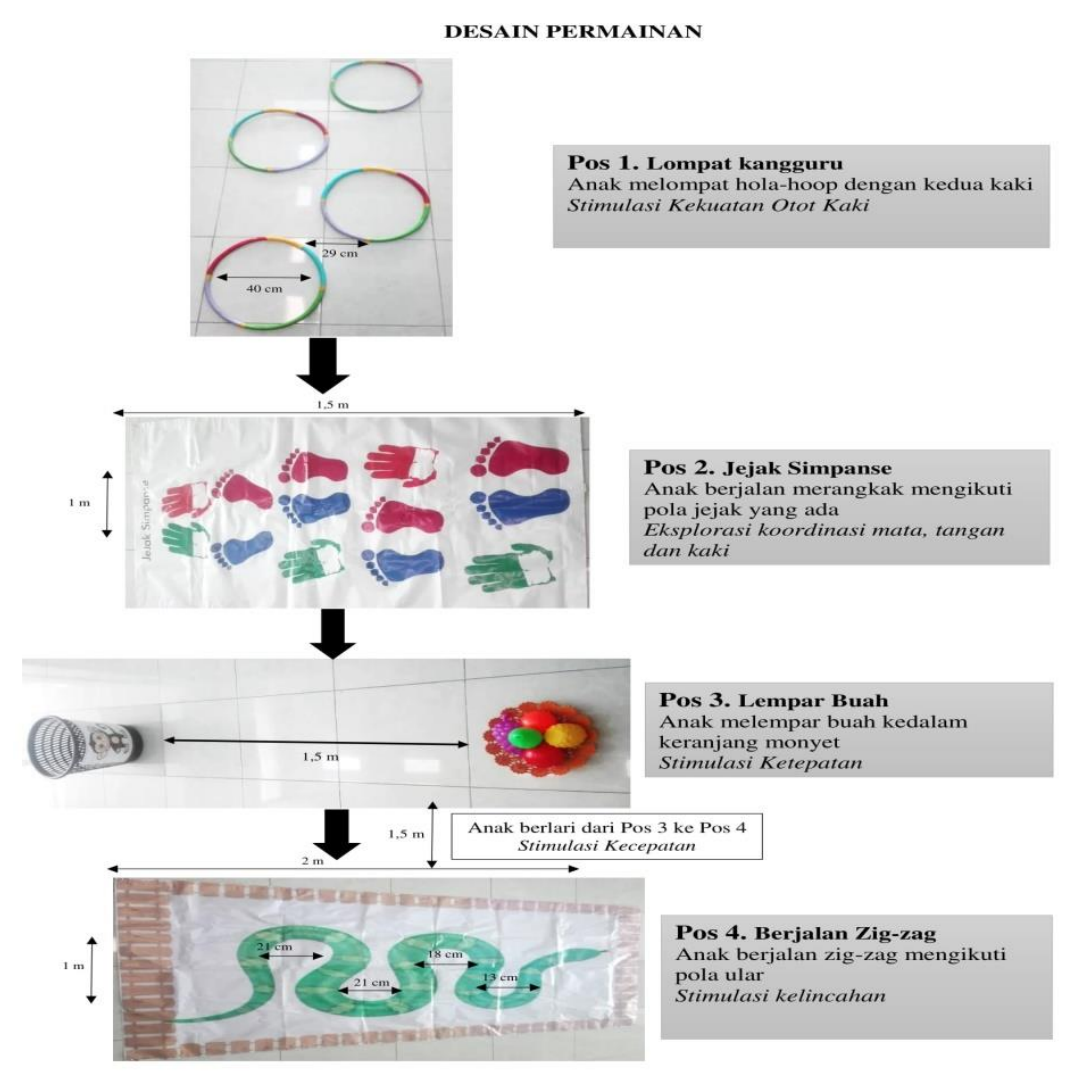

\section{Gambar 4 Desain Permainan}

Sehingga permainan sirkuit Animove ini telah memenuhi syarat alat permainan yang baik untuk anak menurut (Kustiawan, 2015) menyatakan bahwa pemilihan alat permainan harus aman tidak membahayakan, menarik, menyenangkan, dan tidak membosankan bagi anak. Beberapa hal ini telah diperhatikan oleh peneliti dalam membuat alat permainan, seperti memakai cat 
kayu yang aman dan tahan lama, mengampelas atau menghaluskan hula-hoop rotan agar tidak berserat dan tidak tajam. Serta pemilihan penggunaan banner standart outdoor yang tidak licin dan tahan lama. Revisi produk yang telah dilakukan juga sesuai dengan syarat dan kriteria kegiatan bermain menurut (Laili, 2017) agar permainan dapat berjalan secara maksimal permainan harus sesuai dengan aspek perkembangan dan usia anak, sehingga permainan akan mudah dimainkan oleh anak. Pernyataan ini sudah sesuai dengan dengan pemilihan rintangan, jarak dan alat yang digunakan sudah sesuai dengan tingkat perkembangan anak usia 5-6 tahun. Oleh karena itu kegiatan permainan sirkuit Animove dikatakan sangat valid dan sangat layak digunakan untuk menstimulasi keterampilan motorik kasar anak usia 5-6 tahun.

\section{SIMPULAN}

Berdasarkan Data yang diperoleh dari 3 (tiga) ahli terdiri dari 1 ahli permainan menyatakan 97,22\% permainan Animove sangat sesuai dan mudah untuk anak, 1 ahli alat permainan menyatakan 84,09\% permainan sirkuit Animove sangat aman dan menarik untuk anak, 1 ahli fisik motorik menyatakan 96,43\% permainan sirkuit sangat sesuai dalam menstimulasi perkembangan fisik motorik anak usia 5-6 tahun khususnya pada unsur motorik kasar ketepatan, koordinasi, kekuatan, dan kelincahan. Data yang diperoleh dari uji coba kelompok kecil skala terbatas menyatakan bahwa 91,67\% permainan ini aman untuk anak usia 5-6 tahun, 95\% permainan Animove ini mudah untuk anak usia 5-6 tahun dan 96,67\% permainan ini menarik untuk anak usia 5-6 tahun. Produk permainan yang telah dikembangkan menunjukan bahwa permainan Animove yang sangat valid dan sangat layak untuk dimanfaatkan menstimulasi perkembangan fisik-motorik anak usia 5-6 tahun, namun demikian masih ada beberapa hal yang harus diperhatikan seperti sesuai dengan situasi yang ada, usia dan tingkat perkembangan anak.

\section{DAFTAR PUSTAKA}

Akbar, Sa'dun. (2013). Instrumen Perangkat Pembelajaran. Bandung: Rosdakarya.

Farhurohman. (2017). Hakikat Bermain Dan Permainan Anak Usia Dini Di Pendidikan Anak Usia Dini (Paud). 2(1), 27-36. Retrieved from Assibyan

Fadlan, M. N., \& Pratama, A. T. (2019). Pelatihan Pengenalan Aktifitas Fisik Motorik Anak Usia Dini Se-Desa Amplas Kecamatan Percut Sei Tuan Kabupaten Deli Serdang. Prosiding Seminar Nasional Hasil Pengabdian 2019, 510-512.

Hurlock, E. B. 1978. Perkembangan Anak Jilid 1. (Terjemahan Meitasari dan Muslichah). 1988. Jakarta: Erlangga

Kustiawan, U. (2015). Sumber dan Media Pembelajaran AUD.

Kementerian Pendidikan dan Kebudayaan. (2014). Peraturan Menteri Pendidikan dan Kebudayan Nomor 137 Tahun 2014 tentang Standar Pendidikan Anak Usia Dini.

Khurniawati, C. V. (2015). Pengembangan media fun recycle sircuit untuk pembelajaran aspek fisik motorik di Taman Kanak-kanak kelompok $B$. SKRIPSI Jurusan Kependidikan Sekolah Dasar \& Prasekolah-Fakultas IImu Pendidikan UM. 
Laili, R. A. (2017). Meningkatkan Krativitas Anak Usia Dini Melalui Pembuatan Alat Permainan Edukatif (APE).

Murdani, Wahyu. 2015. Pengembangan Model Pembelajaran Kebugaran Jasmani Menggunakan Media Sederhanadari Bahan Bambu Di SMA Negeri 1 Pare. SKRIPSI Jurusan PENJASKESREK-Fakultas IImu Pendidikan Unversitas Nusantara PGRI Kediri.

Noviana, E. (2015). Pengembangan permainan sirkuit hulahop dalam pembelajaran fisik motorik anak Kelompok B di TK Gugus II Kecamatan Srengat Kabupaten Blitar. SKRIPSI Jurusan Kependidikan Sekolah Dasar \& Prasekolah-Fakultas IImu Pendidikan UM.

PERMENDIKBUD. (2014). STPPA Usia 5-6 Tahun PAUD.

Pramono. (2015). Bermain dan Permainan. Malang: Universitas Negeri Malang.

Prasetiawan, A. Y. (2019). Perkembangan Golden Age Dalam Perspektif Pendidikan Islam. Journal of Chemical Information and Modeling, 53(9), 1689-1699. https://doi.org/10.1017/CBO9781107415324.004

Pratiwi, Intan. (2019). Pengembangan Permainan Mini Jungle Circuit Untuk Melatih Kemampuan Berpikir Simbolik Anak Kelompok A di Kota Malang. SKRIPSI Jurusan Kependidikan Sekolah Dasar \& PrasekolahFakultas IImu Pendidikan UM.

Ramsetter, C., \& Murray, R. (2017). Time to play. Recognising the benefits of recess. American Educator, (May), 31-33.

Rismayanthi, C. (2013). Olahraga Kesehatan. In Journal of Chemical Information and Modeling (Vol. https://doi.org/10.1017/CBO9781107415324.004

Sukmadinata. (2005). Metodelogi Penelitian. 